\title{
ROZDZIELANIE KOMUNII ŚW. INFRA MISSAM
}

Nowe rubryki mszału i brewiarza rzymskiego $\mathrm{z}$ dnia 26 lipca $1960 \mathrm{r}$. przewidują w rubryce $\mathrm{Nr} 502$ tempus proprium dla udzielania wiernym Komunii św. Jest to czas po Komunii odprawiającego kapłana, który sam winien rozdawać przystępującym, chyba że z powodu wielkiej ilości komunikujących wypada, aby mu pomógł jeden lub kilku innych kapłanów.

Istnieje jednak następujące zdanie w rubryce 502: Jest zupetnie niewtaściwe (dedecet omnino), aby przy tym samym oltarzu, przy którym aktualnie odprawia się mszę św., inny kapłan rozdawat Komunię św. poza wtaściwa jej pora.

Zdanie to przyjęto rozmaicie. Jedni cieszyli się na nie od dawna. Innił zaczęli wątpić, czy to $\mathrm{w}$ pewnych okolicznościach jest możliwe do przeprowadzenia; jeszcze inni zajęli zdecydowanie negatywne stanowisko, że przepis jest nieaktualny, że jest to przerost liturgii nad duszpasterstwem itd.

Co o tym wszystkim powiemy? Sądzę, że problem leży o wiele głębiej, aniżeli w prostym komentowaniu przepisu rubryk. Problem ten jest historycznym wynikiem rozwoju ruchu eucharystycznego i liturgicznego, które to ruchy ostatnio połączyły się albo w niektórych krajach dążą do połączenia się. Jeżeli weźmiemy pod uwagę ruch eucharystyczriy, to miarodajne są tu dekrety papieża św. Piusa X-go, który przełamał zapatrywania wielu wieków, przesiąkniętych ostatnio jeszcze herezją jansenizmu. Dekret Sacra Tridentina Synodus nie miał jednak na celu określenie liturgicznej zależności Komunii św. od Mszy św. Celem jego było podanie warunków przyjęcia częstej Komunii św. i zachęcenie wiernych, by nie tylko w duchowny sposób lecz sakramentalnie brali udział w Eucharystii. Dekret nie miał - jak wspomniałem na celu liturgicznej łącz. ności Komunii św. ze Mszą św., przeciwnie, tę łączność nawet jeszcze rozluźnił, bo robiono wszystko, aby Komunii św. było jak najwięcej. Przyjmowanie Komunii św. przed Mszą św. było zjawiskiem powszechnym, a Mszę św. uważano b. często za dziękczynienie po Komunii św. A jeżeli przyjmowano już Komunię św. w czasie Mszy św., to modlitwy przygotowawcze do Komunii św. odmawiano w czasie pierwszej części Mszy św. i zupełnie niezależnie od niej.

W. dogmatykach i katechizmach traktowało się Sakrament Ołtarza i IMszę św., jako osobne rozdziały, a przez to naukę o owocach Mszy św. i łaskach Komunii św. zupełnie pozbawiono łączności ze sobą. Pojęcie uczta ofiarna całkowicie zanikło. Tego nie chciał św. Pius X. Przecież jest on równocześnie wielkim promotorem ruchu liturgicznego. Ale sam nie mógł tego zrobić. Do połączenia się obydwu ruchów, eucharystycznego i liturgicznego musiało dojść po pewnym czasie. Trzeba było wychowania całego pokolenia, by to zrozumieć. Waźmy dla przykładu rozmaite wydania Katechetyki Gatterera. W II wydaniu (r. 1911) omawia Gatterer Komunię św. w całkowitym odizolowaniu od Mszy św. Mszę św. omawia w działach Modlitwa i Liturgia i to tylko zdawkowo, podczas gdy nabożeństwo komunijne omówione zostało bardzo szczegółowo. W III wydaniu Katechetyki (1924 r.) znajdujemy już specjalny rozdzial „o eucharystycznym wychowaniu". W części Liturgia jeden z paragrafów poświęcony jest Mszy św., drugi Komunii św. Gatterer nawet uważa za wskazane, by wytłumaczyć się z tego. Myśla Kościoła powiada - nie jest odrywanie Komunii św. od Mszy św., ale ze względów praktycznych trzeba problemy te traktować osobmo. Widzimy w tym wydaniu (III) dużą przemianę, chociaż Msza św. jest tylko jeszcze pót godzina pod krzyżem, a Komunia św. jedzèniem Baranka Wielkanocnego. 
Podkreśloną jednak już jest łączność jednego z drugim. W IV wydaniu (1931) Gatterer omawia wszystkie sakramenty łącznie ze Mszą św. pod Liturgia. Według myśli Chrystusa i jego Kościoła we Mszy św. spełniają się dwa zamiary: ofiara i spożycie darów ofiarnych. Msza i Komunia św. są jedną całością. Uczta ofiarna jest konieczną częścią Mszy św. Tu, w wydaniach Gatterera najlepiej obserwujemy rozwój ruchu liturgicznego, jak łączy się z ruchem eucharystycznym.

To połączenie było konieczne. Ruch eucharystyczny potrzebował ruchu liturgicznego, by nie udusić się $w$ swoich własnych trudnościach (Kramp, Eucharistie 1924). Zapas sił, tkwiących w religijnych uczuciach, których to uczuć żądają książki do nabożeństwa, powoli się wyczerpuje. Bo wszelkie zamknięcia zmysłów dla świata zewnętrznego na dłuższy czas jest niemożliwe, wszelka koncentracja duchowych sił czlowieka jest nie do zniesienia przez dłuższy okres czasu, by codziennie przygotować duszę na przyjście Jezusa.

Aby więc ruch eucharystyczny nie załamal się, musi otrzymać takie podstawy, które by zapewniły mu dalszy rozwój. I dzisiaj jesteśmy już wszyscy zgodni, że wprowadzenie dzieci do Komunii św. musi się odbyć przez wprowadzenie ich do Mszy św. Dziś musimy się zgodzić z tym, że Komunia św. to nie tylko zjednoczenie z Osobą Jezusa (aspekt personalny), ale $\mathrm{i}$ zjednoczenie $\mathrm{z}$ Ciałem Jego, że to Ciało jest rzeczą, res mirabilis, lekarstwem, pokarmem itd. (aspekt rzeczowy). A to jeszcze nie wszystko. Komunia św. jest zjednoczeniem z Ofiarą Jezusa. I o to tu właściwe chodzi. Komunia św. to zjednoczenie ze Mszą św., która jest powtórzeniem ofiary kalwaryjskiej. To organiczna część mszy św. nie tylko dla kapłana, ale i dla wiernych. I to tak dalece, że Pi us XII chwali tych, którzy będac obecni na mszy św. spożywaja hos tie konsekrowane podczas tej Ofiary, aby rzeczywiście doszło do tego, abyśmy wszyscy, tego ottarza uczestnicy, pożywajac Przenajświętsze Ciato $i$ Krew Syna Twego, otrzmali z niebios petnię błogosławieństw i łaski. (Med. Dei wyd. Kielce str. 74).

Czy my tego nie dostrzegamy? Trzeba nam wiedzieć o tym, że nowy dekret Stolicy Apostolskiej o rubrykach mszału i brewiarza rzymskiego przewidując w czasie Iszy św. „Tempus Communionis” idzie właśnie po tej linii dalszego rozwoju: by Komunię św. związać silnie ze Mszą św., by kapłani i wierni to zrozumieli, że Komunia św. wypływa z ofiary, że nie można jej już oddzielić od Ofiary Mszy św. i rozdzielać wiernym przed ,Pater noste". Modlitwa ta ma być wspólną modlitwą kapłana i wiernych przed Komunią św. - o ile to możliwe, ten sam kapłan ma rozdzielać Komunię św. w tej samej Ofierze Mszy św. Podkreślam te słowa „o ile możliwe”. Bo rzeczywiście są okoliczności, gdzie rozdzielanie Komunii św. przez celebransa jest nie do przeprowadzenia, zwłaszcza w niedziele, gdy jedna msza św. goni drugą w ciasnych kościołach, a ilość komunikujących jest duża.

Czy tedy nie ma żadnej możliwości poza rezygnacją z Tempus Communionis? Zanim jednak któryś z księży proboszczów zrezygnuje ze stosowania się do przepisu Stolicy Apostolskiej, musi zastanowić się nad tym, czy nie można znaleźć innego wyjścia, które zachowałoby Tempus Communionis?! Jakie byłyby te wyjścia?

1. Razem z celebransem może komunikować drugi lub trzeci kapłan (o ile jest).

2. Celebrans zacznie komunikować jeden rząd, ręsztę dopełni inny kapłan, gdy czas do następnej Mszy św. jest bardzo krótki.

Te dwie możliwości wydają się być najlepsze. Podkreślona w nich jest bardzo pięknie łączność Komunii z właściwą Ofiarą. Komunia św. przecież Ucztą ofiarną. Tego charakteru Komunii św. - jak wyżej powie- 
działem - nie możemy stracić z przed oczu, inaczej Ruch Eucharystyczny ostatnich lat może znów zawisnąć w próżni, nie oparty o Ofiarę św. Nie możemy dopuścić do tego, by do przepisu kodeksu zastosować się dopiero po 50 latach, gdy ludzie odejdą ponownie od Komunii św., nie znalazłszy w niej - z naszej winy - łączności z Ofiarą św.

3. Dalej można myśleć nad właściwym rozłożeniem ilości Komunii św. na kilka mszy św., zwłaszcza w niedziele. Dzisiejsze przepisy co do postu eucharystycznego nie zostały duszpastersko należycie wykorzystane. Stale jeszcze wierni korzystają z Komunii św. przeważnie w czasie pierwszej Mszy św. a w czasie ostatnich Mszy św. niekiedy nie ma nikogo, gdy tymczasem wierni mogliby nawet zjeść skromne śniadanie, jeżeli Komunię ma się przyjąć np. o godz. 12-tej. I nad tą możliwością trzeba by się zastanowić, by rozładować ilość Komunii św. przy pierwszej Mszy św. zwłaszcza w niedziele.

4. Dalszą możliwością będzie rozdzielanie Komunii św. przy bocznym ołtarzu. Kodeks rubryk (nr 502) podsuwa tę możliwość chyba tylko w nadzwyczajnych wypadkach (jak I piątki), rozdawania Komunii św. przy innym ołtarzu. Będzie to możliwe np. w wielkich kościołach, chociaż sposób ten nie przyczynia się do nawiązania łączności z Ofiarą św.

5. Jeżeli już wszystkie możliwości wyczerpano, trzeba pozostać z konieczności przy dotychczasowym sposobie. Nie może to jednak w żadnym wypadku odbywać się zaraz po Przeistoczeniu, lecz niech będzie po „Pater noster". Nie może to być również praktyką stałą, lecz wyjątkową: przy dużym naplywie wiernych. Mała ilość wiernych powinien zawsze komunikować. sam celebrans. Gdy wiernych jest więcej, drugi kapłan może pomóc, ale praktyka niektórych parafii, gdzie drugi kapłan wychodzi do oltarza tuż po Przeistoczeniu, obojętnie czy jest 20 wiernych czy 200 do komunikowania, jest praktyką niezgodną z duchem liturgii i stoi w kolizji z przepisami kodeksu rubryk. Praktyki tej należy od zaraz zaniechać.

6. Ze słusznej przyczyny wolno rozdawać Komunię św. poza Mszą św. To nie ulega wątpliwości. Ale wychowywać będziemy do zachowania łączności między Komunią św. a ofiarą MIszy św. W wielu wypadkach poza szczególnymi dniami - do Komunii św. poza Mszą św. przystępują osoby starsze, które mogłyby z powodzeniem zostać na Mszy św., ale są nieuświadomione i nie wiedzą, o co chodzi.

Niech przynajmniej proboszcz i kapłan weźmie powyższe pod uwagę. Uczynimy wszystko, by zachować przepisy dekretu. Przyczyny, jak się okazało, są głębsze, niż nam się zdaje, a sięgają również daleko w przyszłość i trzeba się nad nimi zastanowić, zanim ktoś powie: nie można inaczej. Nie możemy dopuścić do tego, by wierni tuż po ostatnim dzwonku na Przeistoczenie, kiedy to właściwie cisza powinna panować w kościele (Instr. o muz. i lit. Nr 277), powstawali $z$ hałasem ze swoich miejsc i spieszyli do Stołu Pańskiego, nie zdając sobie sprawy $z$ tego co się przed chwilą stało i nie pomodliwszy się przedtem wspólnie z kapłanem „Ojcze nasz”, jak na dzieci Boże przystało.

Katowice

Ks. ROMUALD RAK

\section{NOWY DOKTÓR NAUK BIBLIJNYCH W POLSCE}

18 października br. na Papieskim Instytucie Biblijnym (Biblicum) w Rzymie, ks. dr Lech Remigiusz Stachowiak, profesor egzegezy Łódzkiego Seminarium Duchownego uzyskał stopień doktora nauk biblijnych broniąc publicznie tezy doktorskiej Paranezy u św. Pawła $i$ pouczenie o dwóch duchach $w$ Qumrân (Die paulinischen Paränesen und die 